\title{
Air- and Moisture-Stable Cyclopalladated Complexes as Efficient Catalysts for Suzuki-Miyaura Coupling Reaction
}

\author{
Chuan-Lin Chen, Yi-Hung Liu, Shie-Ming Peng, and Shiuh-Tzung Liu* \\ Department of Chemistry, National Taiwan University, Taipei, Taiwan 106, Republic of China
}

Received November 11, 2004

\begin{abstract}
A series of cylcopalladated complexes containing a six-membered chelating ring with the general formula $\left[\mathrm{Pd}(\mathrm{Cl})\left(k^{2} N, C-\mathrm{CH}_{2} \mathrm{C}_{6} \mathrm{H}_{2}(\mathrm{Me})_{2} \mathrm{CH}=\mathrm{NAr}\right)\right]_{2}$ [where $\mathrm{Ar}=2,6-(\mathrm{Me})_{2} \mathrm{C}_{6} \mathrm{H}_{3}-(\mathbf{3 a})$; 2,6- $\left.\left.{ }^{(} \mathrm{Pr}\right)_{2} \mathrm{C}_{6} \mathrm{H}_{3}-(\mathbf{3 b})\right]$ and the related phosphine-substituted species $\left[\mathrm{PdCl}\left(k^{2} N, C-\mathrm{CH}_{2} \mathrm{C}_{6} \mathrm{H}_{2}(\mathrm{Me})_{2^{-}}\right.\right.$ $\left.\mathrm{CH}=\mathrm{NAr})\left(\mathrm{PR}_{3}\right)\right]\left[\mathrm{Ar}=2,6-(\mathrm{Me})_{2} \mathrm{C}_{6} \mathrm{H}_{3}-, \mathrm{R}=\mathrm{Cy}(\mathbf{5 a}) ; \mathrm{Ar}=2,6-\left({ }^{i} \mathrm{Pr}_{2} \mathrm{C}_{6} \mathrm{H}_{3}, \mathrm{R}=\mathrm{Cy}(\mathbf{5 b}) ; \mathrm{Ar}=\right.\right.$ 2,6-(Me $\left.)_{2} \mathrm{C}_{6} \mathrm{H}_{3}-, \mathrm{R}=\mathrm{Ph}(\mathbf{5 c}) ; \mathrm{Ar}=2,6-\left({ }^{(} \mathrm{Pr}\right)_{2} \mathrm{C}_{6} \mathrm{H}_{3}-, \mathrm{R}=\mathrm{Ph}(\mathbf{5 d})\right]$ have been synthesized. In addition, an ortho-metalated complex $\left[\mathrm{PdCl}\left(k^{2} N, C-\mathrm{C}_{6} \mathrm{H}_{4} \mathrm{CH}=\mathrm{N}\left(2,6-{ }^{i} \mathrm{Pr}_{2} \mathrm{C}_{6} \mathrm{H}_{3}\right)\right)\left(\mathrm{PCy}_{3}\right)\right](7)$ was prepared by a similar manner. Crystal structures of $\mathbf{3 a}, \mathbf{5 b}, \mathbf{c}$, and $\mathbf{7}$ have been determined. The use of these palladium complexes as catalysts for Suzuki-Miyaura coupling reaction of aryl halides with arylboronic acids in ethanol solution was examined. It is found that this series of palladacycles are considerably active under aerobic conditions. Typically, the best activity (TON $\approx 10^{6}$ ) is seen with $\mathbf{3 a}, \mathbf{b}$ in the coupling reaction of aryl bromide with phenylboronic acid. However, a TEM study showed that the palladium nanoparticles were formed under the reaction conditions, which might be the active species for the catalysis.
\end{abstract}

\section{Introduction}

Suzuki-Miyaura coupling reaction provides a powerful method for preparation of unsymmetrical biaryls, ${ }^{1}$ and the palladium complexes are known to be the most efficient catalyst among various metal systems. However, a high loading of catalyst and an inert atmosphere in most reactions are generally required for a better conversion, which does not meet the requirements in both an economical and an environmental sense. ${ }^{1-6}$ Thus searching for new palladium complexes as catalysts has received much attention particularly for the use of aryl chloride as substrates, ${ }^{2-8}$ under aerobic conditions ${ }^{4}$ or even in aqueous solution. ${ }^{5}$ Accordingly, palladacycles were found to the most promising catalysts in this regard. ${ }^{1 d, 6-8}$ Recently, Bedford ${ }^{7}$ and Nájera ${ }^{8}$ have demonstrated that Suzuki coupling reaction of aryl chlorides with arylboronic acid in high conversion can be achieved by using the cyclopalladated imino complexes $\mathbf{1}$ and $\mathbf{2}$, respectively. In a previous communication, we have found that palladium complex $\mathbf{3 b}$ could act as a catalyst for the coupling of aryl chloride with arylboronic acid in aqueous medium. ${ }^{9}$ Here, we would like to report the detailed studies of the preparation and characterization of a series of benzylic palladacyles as

\footnotetext{
* To whom correspondence should be addressed. E-mail: stliu@ntu.edu.tw.

(1) Recent reviews: (a) Suzuki, A. J. Organomet. Chem. 1999, 576, 147. (B) Stanforth, S. P. Tetrahedron 1998, 54, 263. (c) Hassan, J.; Sevignon, M.; Gozzi, C.; Schulz, E.; Lemaire, M. Chem. Rev. 2002, 102, 1359. (d) Bedford, R. B. Chem. Commun. 2003, 1787. (e) Tucker, C. E.; De Vries, J. G. Top. Catal. 2002, 19, 111. (f) Singleton, J. T. Tetrahedron 2003, 59, 1837. (g) Kotha, S.; Lahiri, K.; Kashinath, D. Tetrahedron 2002, 58, 9633-9695. (h) Marshall, J. A. Chemtracts 2000 , 13, 219. (i) Kocovsky, P.; Malkov, A. V.; Vyskocil, S.; Lloyd-Jones, G. C. Pure Appl. Chem. 1999, 71, 1425-1433. (j) Herrmann, W. A. Applied Homogeneous Catalysis with Organometallic Compounds, 2nd ed.; 2002; Vol. 1, 591 pp.
}

well as their catalytic activities toward Suzuki-Miyaura coupling reaction in ethanol under an aerobic atmosphere.
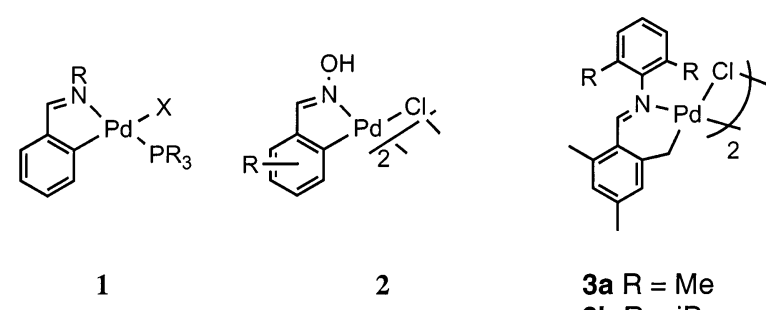

2

$$
\begin{aligned}
& \text { 3a } R=M e \\
& \text { 3b } R=i P r
\end{aligned}
$$

(2) (a) Na, Y.; Park, S.; Han, S. B.; Han, H.; Ko, S.; Chang, S. J. Am. Chem. Soc. 2004, 126, 250. (b) Brase, S.; Kirchhoff, J. H.; Kobberling, J. Tetrahedron 2003, 59, 885. (c) Kranich, R.; Eis, K.; Geis, O.; Muhle, S.; Bats, J. W.; Schmalz, H. G. Chem. Eur. J. 2000, 6, 2874. (d) Tao, B.; Boykin, D. W. Tetrahedron Lett. 2002, 43, 4955. (e) Kolodziuk, R.; Penciu, A.; Tollabi, M.; Framery, E.; Goux-Henry, C.; Iourtchenko, A.; Sinou, D. J. Organomet. Chem. 2003, 687, 384. (f) Feuerstein, M.; Doucet, H.; Santelli, M. J. Organomet. Chem. 2003, 687, 327. (g) McLachlan, F.; Mathews, C. J.; Smith, P. J.; Welton, T. Organometallics 2003, 22, 5350. (h) Loch, J. A.; Albrecht, M.; Peris, E.; Mata, J.; Faller, J. W.; Crabtree, R. H. Organometallics 2002, 21, 700. (i) Gstottmayr, C. W. K.; Bohm, V. P. W.; Herdtweck, E.; Grosche, M.; Herrmann, W. A. Angew. Chem., Int. Ed. 2002, 41, 1363. (j) Sava, X.; Ricard, L.; Mathey, F.; Le Floch, P. Organometallics 2000, 19, 4899. (k) Zhang, C. M.; Trudell, M. L. Tetrahedron Lett. 2000, 41, 595.

(3) Aryl chlorides as substrates for Suzuki couplings; see: (a) Li, G. Y. J. Org. Chem. 2002, 67, 3643. (b) Liu, S.-Y.; Choi, M. J.; Fu, G. C. Chem. Commun. 2001, 2408. (c) Netherton, M. R.; Fu, G. C. Org. Lett. 2001, 3, 4295. (d) Zapf, A.; Ehrentraut, A.; Beller, M. Angew. Chem., Int. Ed. 2000, 39, 4153. (e) Old, D. W.; Wolfe, J. P.; Buchwald, S. L. J. Am. Chem. Soc. 1998, 120, 9722. (f) Bei, X.; Turner, H. W.; Weinberg, W. H.; Guram, A. S. J. Org. Chem. 1999, 64, 6797. (g) Zhang, C.; Huang, J.; Trudell, M. L.; Nolan, S. P J. Org. Chem. 1999, 64, 3804. (h) Navarro, O.; Kelly, R. A.; Nolan, S. P. J. Am. Chem. Soc. 2003, 125, 16194. (i) Navarro, O.; Oonishi, Y.; Kelly, R. A.; Stevens, E. D.; Briel, O.; Nolan, S. P. J. Organomet. Chem. 2004, 689, 3722, and references therein. 
Scheme 1. Preparation of Palladacycles

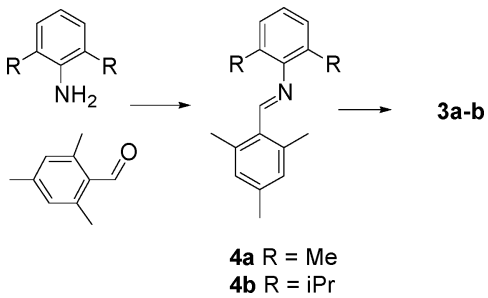

\section{Results and Discussion}

Preparation of Ligands and Complexes. Substituted trimethylbenzylideneamines were prepared by the condensation of 2,4,6-trimethylbenzaldehyde with a substituted aniline (Scheme 1). Both infrared absorptions near $1626 \mathrm{~cm}^{-1}$ and ${ }^{13} \mathrm{C} \mathrm{NMR}$ shifts around 162-163 ppm of imines $\mathbf{4 a}, \mathbf{b}$ are characteristic of the functionality of $\mathrm{C}=\mathrm{N}$. Cyclopalladation reactions were carried out in a mixture of $\left(\mathrm{CH}_{3} \mathrm{CN}\right)_{2} \mathrm{PdCl}_{2}$, sodium acetate, and the corresponding ligand in tetrahydrofuran at ambient temperature for $38 \mathrm{~h}$. The desired palladium products $\mathbf{3 a}, \mathbf{b}$ were isolated as air-stable solids upon crystallization. In both instances, the cyclopalladation readily occurs at the benzylic position to form an endo six-membered chelating ring, and the product is in a chloro-bridged dipalladium structure, which is consistent with most of the related species. ${ }^{10}$ The $\mathrm{C}-\mathrm{H}$ activation at the benzylic position is established by their ${ }^{1} \mathrm{H}$ NMR and X-ray single-crystal determination. The appearance of a signal at $3.19 \mathrm{ppm}$ for $3 \mathbf{a}$ and 3.24 for $3 \mathbf{b}$ with the integration of $2 \mathrm{H}$ in the ${ }^{1} \mathrm{H}$ NMR spectra was assigned to the methylene protons of $\mathrm{Pd}-\mathrm{CH}_{2}-$ resulting from the $\mathrm{C}-\mathrm{H}$ activation with the palladium complex.

The detailed structure of palladacyle $\mathbf{3 a}$ was proved by an X-ray diffraction study on single crystals grown from a hexane/dichloromethane solution, whereas the structural characterization of $\mathbf{3 b}$ has been published previously. ${ }^{9}$ Figure 1 displays the ORTEP plot of $\mathbf{3 a}$, and Table 1 summarizes the selected bond distances,

(4) (a) Najera, C.; Gil-Molto, J.; Karlstroem, S.; Falvello, L. R. Org. Lett. 2003, 5, 1451. (b) Badone, D.; Baroni, M.; Cardamone, R.; Ielmini, A.; Guzzi, U. J. Org. Chem. 1997, 62, 7170. (c) Oehme, G.; Grassert, I.; Paetzold, E.; Meisel, R.; Drexler, K.; Fuhrmann, H. Coord. Chem. Rev. 1999, 185-186, 585

(5) (a) Venkatraman, S.; Li, C.-J. Org. Lett. 1999, 1, 1133. (b) Jensen, J. F.; Johannsen, M. Org. Lett. 2003, 5, 3025

(6) (a) Dupont, J.; Pfeffer, M.; Spencer, J. Eur. J. Inorg. Chem. 2001 1917. (b) Herrmann, W. A.; Böhm, V. P. W.; Reisinger, C.-P $J$. Organomet. Chem. 1999, 576, 23. (c) Dyker, G. Chem. Ber./Recl. 1997 130, 1567. (d) Ryabov, A. D. Synthesis 1985, 233.

(7) (a) Bedford, R. B.; Cazin, C. S. J.; Coles, S. J.; Gelbrich, T.; Horton, P. N.; Hursthouse, M. B.; Light, M. E. Organometallics 2003, 22, 987. (b) Bedford, R. B.; Blake, M. E.; Butts, C. P.; Holder, D. Chem. Commun. 2003, 466. (c) Bedford, R. B.; Cazin, C. S. J.; Coles, S. J.; Gelbrich, T.; Hursthouse, M. B.; Scordia, V. J. M. Dalton Trans. 2003, 3350. (d) Bedford, R. B.; Cazin, C. S. J. Chem. Commun. 2001 1540. (e) Bedford, R. B.; Cazin, C. S. J.; Hursthouse, M. B.; Light, M. E.; Pike, K. J.; Wimperis, S. J. Organomet. Chem. 2001, 633, 171.

(8) (a) Alonso, D. A.; Nájera, C.; Pacheco, M. C. J. Org. Chem. 2002 67, 5588. (b) Botella, L.; Nájera, C. Angew. Chem., Int. Ed. 2002, 41, 179.

(9) Chen, C.-L.; Liu, Y.-H.; Peng, S.-M.; Liu, S.-T. Tetrahedron Lett., in press.

(10) (a) Albert, J.; Ceder, R. M.; Gomez, M.; Granell, J.; Sales, J. Organometallics 1992, 11, 1536. (b) Bosque, R.; Granell, J.; Sales, J.; Font-Bardia, M.; Solans, X. J. Organomet. Chem. 1993, 453, 147. (c) Lopez, C.; Perez, S.; Solans, X.; Font-Bardia, M. J. Organomet. Chem. 2002, 650, 258. (d) De Munno, G.; Ghedini, M.; Neve, F. Inorg. Chim. Acta 1995, 239, 155. (e) Albert, J.; Granell, J.; Sales, J.; Solans, X.; Font-Altaba, M. Organometallics 1986, 5, 2567.

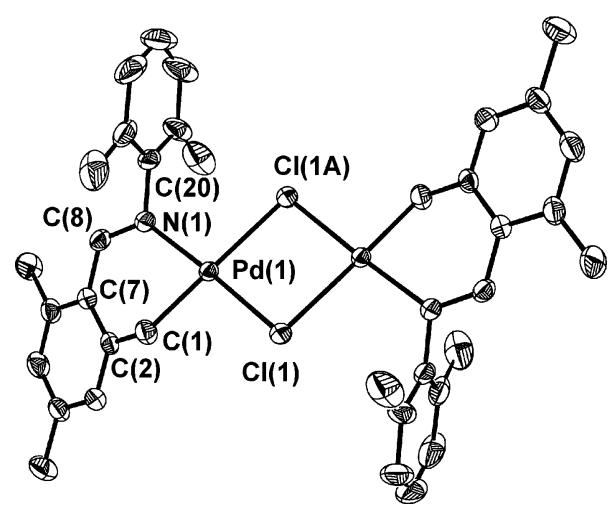

Figure 1. ORTEP drawing of 3a (drawn with $30 \%$ probability ellipsoids; labeling of phenyl groups is omitted for clarity).

Table 1. Selected Bond Distances $(\AA ̊)$ and Bond Angles (deg) of 3a and $3 b$

\begin{tabular}{lll}
\hline & \multicolumn{1}{c}{$\mathbf{3 a}$} & $\mathbf{3 b}^{a}$ \\
\hline $\mathrm{Pd}(1)-\mathrm{N}(1)$ & $2.024(3)$ & $2.043(3)$ \\
$\mathrm{Pd}(1)-\mathrm{C}(1)$ & $2.002(3)$ & $2.003(4)$ \\
$\mathrm{Pd}(1)-\mathrm{Cl}(1)$ & $2.3283(7)$ & $2.498(1)$ \\
$\mathrm{Pd}(1)-\mathrm{Cl}(1 \mathrm{~A})$ & $2.5051(8)$ & $2.325(1)$ \\
$\mathrm{N}(1)-\mathrm{C}(7)$ & $1.298(4)$ & $1.280(5)$ \\
$\mathrm{N}(1)-\mathrm{Pd}(1)-\mathrm{C}(1)$ & $86.0(1)$ & $86.2(1)$ \\
$\mathrm{Pd}(1)-\mathrm{N}(1)-\mathrm{C}(7)$ & $126.5(2)$ & $126.6(3)$ \\
$\mathrm{Pd}(1)-\mathrm{C}(1)-\mathrm{C}(2)$ & $115.8(2)$ & $116.0(3)$ \\
$\mathrm{N}(1)-\mathrm{Pd}(1)-\mathrm{Cl}(1)$ & $176.95(8)$ & $97.28(8)$ \\
$\mathrm{N}(1)-\mathrm{Pd}(1)-\mathrm{Cl}(1 \mathrm{~A})$ & $96.96(7)$ & $176.42(9)$ \\
$\mathrm{C}(1)-\mathrm{Pd}(1)-\mathrm{Cl}(1)$ & $91.11(9)$ & $90.3(1)$ \\
$\mathrm{C}(1)-\mathrm{Pd}(1)-\mathrm{Cl}(1 \mathrm{~A})$ & $174.7(1)$ & $171.2(1)$ \\
$\mathrm{Cl}(1)-\mathrm{Pd}(1)-\mathrm{Cl}(1 \mathrm{~A})$ & $85.81(3)$ & $86.29(3)$
\end{tabular}

Torsion Angles (deg) along the Chelate Ring of 3a $\mathrm{Pd}(1)-\mathrm{N}(1)-\mathrm{C}(7)-\mathrm{C}(8) \quad-2.0 \quad \mathrm{C}(8)-\mathrm{C}(2)-\mathrm{C}(1)-\mathrm{Pd}(1) \quad-47.2$ $\mathrm{N}(1)-\mathrm{C}(7)-\mathrm{C}(8)-\mathrm{C}(2) \quad 22.8 \quad \mathrm{C}(2)-\mathrm{C}(1)-\mathrm{Pd}(1)-\mathrm{N}(1) \quad 49.6$ $\mathrm{C}(7)-\mathrm{C}(8)-\mathrm{C}(2)-\mathrm{C}(1) \quad 4.6 \quad \mathrm{C}(1)-\mathrm{Pd}(1)-\mathrm{N}(1)-\mathrm{C}(7) \quad-29.5$

${ }^{a}$ Reference 9.

bond angles, and torsion angles. In both instances, the palladium metal displays a slightly distorted squareplanar geometry with nitrogen and carbon donors in cisfashion. All bond distances and bond angles lie within normal ranges, which are essentially similar to those for 3b except $\mathrm{Pd}(1)-\mathrm{N}(1)$. The distance of $\mathrm{Pd}(1)-\mathrm{N}(1)$ $[2.024(3) \AA]$ for $\mathbf{3 a}$ is slightly shorter than that for $\mathbf{3 b}$ $[2.043(3) \AA]$, which is attributed to steric differences between methyl and isopropyl groups. The length of $\mathrm{C}(7)-\mathrm{N}(1)[1.298(4) \AA]$ is characteristic for a $\mathrm{C}=\mathrm{N}$ double bond. The small bite angle $\mathrm{N}(1)-\mathrm{Pd}(1)-\mathrm{C}(1)$ $\left[86.0(1)^{\circ}\right]$ is similar to those benzylic-type palladacycles reported by Sales and co-workers. ${ }^{10 \mathrm{e}}$ It is noticed that the angle $\mathrm{Pd}(1)-\mathrm{C}(1)-\mathrm{C}(2)\left[115.8(2)^{\circ}\right]$ deviating from the angle for a tetrahedral geometry, similar to that for $\mathbf{3 b}$, is presumably due to the strain forced by the chelating rings. The dihedral angles along the chelating ring of $\mathrm{Pd}(1)-\mathrm{N}(1)-\mathrm{C}(8)-\mathrm{C}(7)-\mathrm{C}(2)-\mathrm{C}(1)$ in $\mathbf{3 a}$ (Table 1) indicate that this ring is adopted into a twist halfchair conformation, apparently resulting from the occurrence of two double bonds in the chelate ring.

Phosphine-Substituted Complexes. Both palladacycles $\mathbf{3 a}$ and $\mathbf{3 b}$ readily underwent ligand substitution reaction with phosphines (eq 1) to give the corresponding complex. Both complexes were in air-stable crystalline forms. The appearance of only one signal around $40 \mathrm{ppm}$ in the ${ }^{31} \mathrm{P}$ NMR spectra for both 


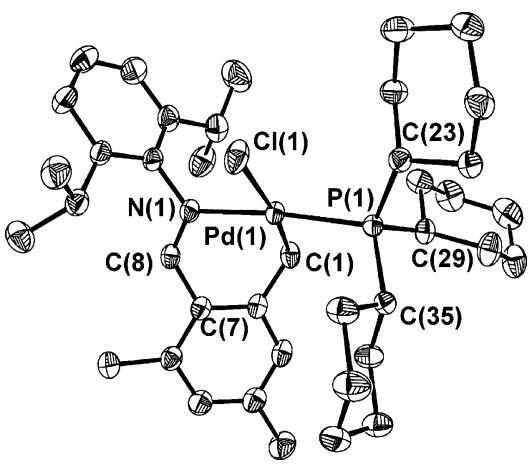

Figure 2. Molecular structure of 5b (30\% probability ellipsoids).

Table 2. Selected Bond Distances (̊̊), Bond Angles (deg), and Torsional Angles (deg) of 5b, 5d, and 7

\begin{tabular}{llll}
\hline & \multicolumn{1}{c}{$\mathbf{5 b}$} & \multicolumn{1}{c}{$\mathbf{5 d}$} & \multicolumn{1}{c}{$\mathbf{7}$} \\
\hline $\mathrm{Pd}(1)-\mathrm{N}(1)$ & $2.148(2)$ & $2.144(2)$ & $2.109(2)$ \\
$\mathrm{Pd}(1)-\mathrm{C}(1)$ & $2.037(3)$ & $2.049(3)$ & $2.016(2)$ \\
$\mathrm{Pd}(1)-\mathrm{Cl}(1)$ & $2.4136(9)$ & $2.3682(8)$ & $2.3904(7)$ \\
$\mathrm{Pd}(1)-\mathrm{P}(1)$ & $2.2683(7)$ & $2.2388(7)$ & $2.3049(7)$ \\
$\mathrm{N}(1)-\mathrm{C}(8)$ & $1.275(4)$ & $1.282(3)$ & $1.279(3)$ \\
$\mathrm{P}(1)-\mathrm{Pd}(1)-\mathrm{N}(1)$ & $174.30(7)$ & $172.67(6)$ & $171.69(6)$ \\
$\mathrm{C}(1)-\mathrm{Pd}(1)-\mathrm{N}(1)$ & $82.7(1)$ & $84.2(1)$ & $80.22(9)$ \\
$\mathrm{P}(1)-\mathrm{Pd}(1)-\mathrm{Cl}(1)$ & $94.62(9)$ & $95.25(3)$ & $89.87(2)$ \\
$\mathrm{C}(1)-\mathrm{Pd}(1)-\mathrm{Cl}(1)$ & $171.62(9)$ & $170.19(6)$ & $168.73(7)$ \\
$\mathrm{P}(1)-\mathrm{Pd}(1)-\mathrm{C}(1)$ & $93.1(1)$ & $88.57(9)$ & $101.38(7)$ \\
$\mathrm{Pd}(1)-\mathrm{N}(1)-\mathrm{C}(8)$ & $118.9(2)$ & $120.5(2)$ & $112.1(2)$ \\
$\mathrm{Pd}(1)-\mathrm{N}(1)-\mathrm{C}(8)-\mathrm{C}(7)$ & -8.94 & 2.72 & \\
$\mathrm{~N}(1)-\mathrm{C}(8)-\mathrm{C}(7)-\mathrm{C}(2)$ & -29.07 & -30.28 & \\
$\mathrm{C}(8)-\mathrm{C}(7)-\mathrm{C}(2)-\mathrm{C}(1)$ & 6.41 & -6.86 & \\
$\mathrm{C}(7)-\mathrm{C}(2)-\mathrm{C}(1)-\mathrm{Pd}(1)$ & 47.88 & 60.11 & \\
$\mathrm{C}(2)-\mathrm{C}(1)-\mathrm{Pd}(1)-\mathrm{N}(1)$ & -61.32 & -62.74 & \\
$\mathrm{C}(1)-\mathrm{Pd}(1)-\mathrm{N}(1)-\mathrm{C}(8)$ & 47.31 & 39.23 &
\end{tabular}

complexes $\mathbf{5 a}$ and $\mathbf{5 b}$ suggests the formation of a single trialkylphosphine-substituted isomer out of the two possibilities. The benzylic methylene unit cis to the phosphorus in $\mathbf{5 a}$ and $\mathbf{5 b}$ was established from the ${ }^{1} \mathrm{H}$ NMR spectra, where the methylene group bound to the palladium appears as a doublet with a coupling constant $J_{\mathrm{P}-\mathrm{H}} \approx 2-5 \mathrm{~Hz}$. This value is in the typical range reported for the cis-arrangement of the methylene group and phosphine in related species. ${ }^{10 a, e}$ Even though both complexes could be easily characterized by means of spectral and elemental analysis, the crystal structure of $\mathbf{5 b}$ was determined to confirm the details. Figure 2 displays the ORTEP drawing of $\mathbf{5 b}$, and selected bond distances and bond angles are collected in Table 2. A method similar to that for the preparation of $\mathbf{5 a}, \mathbf{b}$ was employed to produce the triphenylphosphine adduct $\mathbf{5 c , d}$. Both spectroscopic and crystallographic analyses of $\mathbf{5 d}$ verify the structure of $\mathbf{5 c}, \mathbf{d}$ (Figure 3).

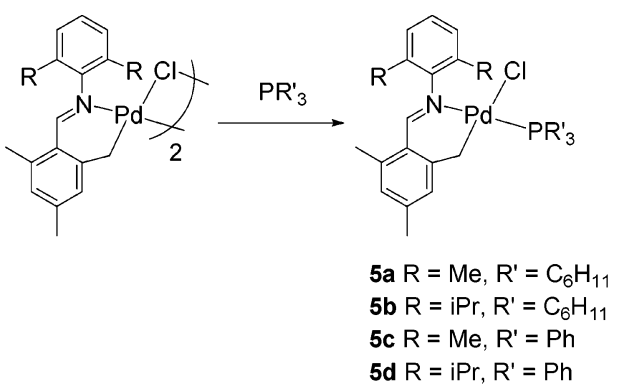

Both $\mathbf{5 b}$ and $\mathbf{5 d}$ show the square planar arrangement around the metal center with the phosphine and imine

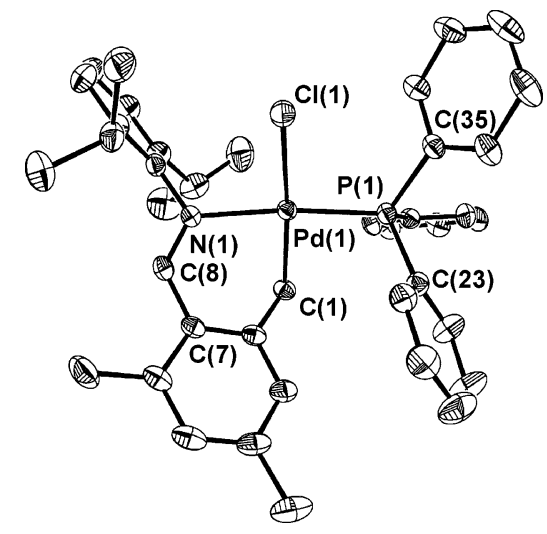

Figure 3. ORTEP plot of $\mathbf{5 d}$ (30\% probability ellipsoids).

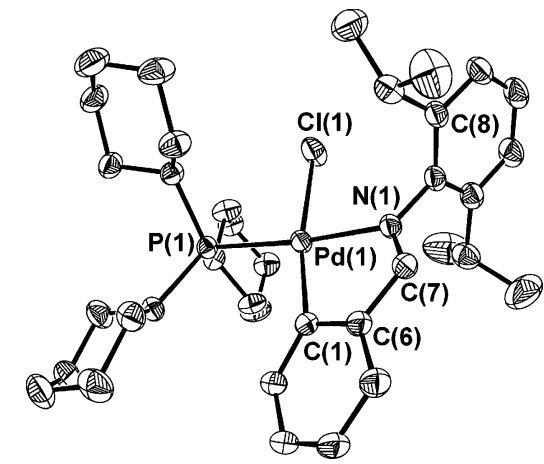

Figure 4. Molecular structure of 7 (30\% probability ellipsoids).

donor trans to each other, presumably due to the trans influence of these donors. All bond distances and bond angles lie in the normal range of closely related complexes such as $\left[\mathrm{Pd}(\mathrm{TFA})\left(\kappa^{2} \mathrm{~N}, \mathrm{C}-\mathrm{C}_{6} \mathrm{H}_{4} \mathrm{CH}_{2} \mathrm{NMe}_{2}\right)\left(\mathrm{PCy}_{3}\right)\right]$ reported by Bedford and co-workers. ${ }^{7 a}$ When two structures are compared, it is found that all bond distances and bond angles around the metal center are very close except the bond angle of $\mathrm{P}(1)-\mathrm{Pd}(1)-\mathrm{C}(1)$ and the bond length of $\mathrm{Pd}-\mathrm{P}$. The $\mathrm{P}(1)-\mathrm{Pd}(1)-\mathrm{C}(1)$ in $\mathbf{5 b}\left[93.1(1)^{\circ}\right]$ is considerably larger than that of the analogous angle in 5d $\left[88.57(9)^{\circ}\right]$, reflecting a result of steric relief between the carbon donor and tricyclohexylphosphine. The $\mathrm{Pd}-\mathrm{P}$ bond distance of $\mathbf{5 b}[2.2683(7) \AA]$ is slightly longer than that of $\mathbf{5 d}[2.2388$ (7) $\AA$ ], which is due to the contribution of palladium back-donation to the $\pi$-acidic nature of triphenylphosphine. The conformation of chelating rings associated with the metal center in $\mathbf{5 b}$ and $\mathbf{5 d}$ remains a twist half-chair form, as illustrated by the torsional angles along the ring consisting of $\mathrm{Pd}(1)-\mathrm{N}(1)-\mathrm{C}(8)-\mathrm{C}(7)-\mathrm{C}(2)-\mathrm{C}(1)$ (Table 2).

Another phosphine-substituted palladacycle, 7, with a five-membered chelating ring was prepared via the substitution of $\mathbf{6}$ with tricyclohexylphosphine (eq 2). The ${ }^{31} \mathrm{P}$ NMR chemical shift of $\mathbf{7}$ appeared at 43.1 $\mathrm{ppm}$, which is in the typical range of trialkylphosphine palladium complexes. ${ }^{7 a, c}$ The crystal structure of 7 was determined (Figure 4). As expected, the molecular structure of $\mathbf{7}$ shows a square planar geometry around the metal center. Out of four coordination sites, two are occupied by an $\mathrm{N}-\mathrm{C}$ ligand in cis-fashion and the other two by phosphine and chloride with nitrogen and phosphorus donors in trans arrangement. The bond lengths between the $\mathrm{Pd}$ and $\mathrm{C}, \mathrm{N}, \mathrm{P}$, and chloride donor atoms for $\mathbf{7}$ (Table 2) are within the range and compa- 
Table 3. Results of Coupling Reactions Catalyzed by Palladacycles ${ }^{a}$

\begin{tabular}{|c|c|c|c|c|c|c|}
\hline entry & cat. (Pd mmol) & $\mathrm{ArBr}$ & {$[\mathrm{ArBr}] /[\mathrm{Pd}]$} & atm & $t(\mathrm{~h})$ & $\operatorname{conv}^{b}(\%)$ \\
\hline 1 & $\mathbf{3 a}\left(1 \times 10^{-4}\right)$ & $p-\mathrm{MeOC}_{6} \mathrm{H}_{4} \mathrm{Br}$ & 20000 & air & 3 & 100 \\
\hline 2 & $\mathbf{3 a}\left(2 \times 10^{-5}\right)$ & $p-\mathrm{MeOC}_{6} \mathrm{H}_{4} \mathrm{Br}$ & 100000 & air & 10 & 91 \\
\hline 3 & $\mathbf{3 a}\left(2 \times 10^{-6}\right)$ & $p-\mathrm{MeOC}_{6} \mathrm{H}_{4} \mathrm{Br}$ & 1000000 & air & 18 & 62 \\
\hline 4 & $\mathbf{3 a}\left(2 \times 10^{-3}\right)$ & $p-\mathrm{MeOC}_{6} \mathrm{H}_{4} \mathrm{Br}$ & 1000 & air & $20^{c}$ & 100 \\
\hline 5 & $\mathbf{3 b}\left(1 \times 10^{-4}\right)$ & $p-\mathrm{MeOC}_{6} \mathrm{H}_{4} \mathrm{Br}$ & 20000 & air & 3 & 100 \\
\hline $6^{d}$ & $\mathbf{3 b}\left(1 \times 10^{-4}\right)^{e}$ & $p-\mathrm{MeOC}_{6} \mathrm{H}_{4} \mathrm{Br}$ & 20000 & air & 3 & 75 \\
\hline $7^{e}$ & $\mathbf{3 b}\left(1 \times 10^{-4}\right) f$ & $p-\mathrm{MeOC}_{6} \mathrm{H}_{4} \mathrm{Br}$ & 20000 & air & 3 & 28 \\
\hline $8^{f}$ & $\mathbf{3 b}\left(1 \times 10^{-4}\right)$ & $p-\mathrm{MeOC}_{6} \mathrm{H}_{4} \mathrm{Br}$ & 20000 & air & 3 & 100 \\
\hline 9 & $\mathbf{3 b}\left(1 \times 10^{-4}\right)$ & $p-\mathrm{MeOC}_{6} \mathrm{H}_{4} \mathrm{Br}$ & 20000 & air & 3 & 64 \\
\hline 10 & $\mathbf{3 b}\left(2 \times 10^{-5}\right)$ & $p-\mathrm{MeOC}_{6} \mathrm{H}_{4} \mathrm{Br}$ & 100000 & air & 10 & 86 \\
\hline 11 & $\mathbf{3 b}\left(2 \times 10^{-6}\right)$ & $p-\mathrm{MeOC}_{6} \mathrm{H}_{4} \mathrm{Br}$ & 1000000 & air & 20 & 57 \\
\hline 12 & $\mathbf{3 b}\left(2 \times 10^{-3}\right)$ & $p-\mathrm{MeOC}_{6} \mathrm{H}_{4} \mathrm{Br}$ & 1000 & air & $14^{c}$ & 100 \\
\hline 13 & 5c $\left(1 \times 10^{-4}\right)$ & $p-\mathrm{MeOC}_{6} \mathrm{H}_{4} \mathrm{Br}$ & 20000 & air & 3 & 85 \\
\hline 14 & $\mathbf{5 d}\left(1 \times 10^{-4}\right)$ & $p-\mathrm{MeOC}_{6} \mathrm{H}_{4} \mathrm{Br}$ & 20000 & air & 3 & 95 \\
\hline 15 & $\mathbf{5 a}\left(1 \times 10^{-4}\right)$ & $p-\mathrm{MeOC}_{6} \mathrm{H}_{4} \mathrm{Br}$ & 20000 & air & 3 & 100 \\
\hline 16 & $\mathbf{5 b}\left(1 \times 10^{-4}\right)$ & $p-\mathrm{MeOC}_{6} \mathrm{H}_{4} \mathrm{Br}$ & 20000 & air & 3 & 92 \\
\hline 17 & $6\left(1 \times 10^{-4}\right)$ & $p-\mathrm{MeOC}_{6} \mathrm{H}_{4} \mathrm{Br}$ & 20000 & air & 3 & 86 \\
\hline 18 & $6\left(2 \times 10^{-6}\right)$ & $p-\mathrm{MeOC}_{6} \mathrm{H}_{4} \mathrm{Br}$ & 1000000 & air & 16 & 26 \\
\hline 19 & $7\left(1 \times 10^{-4}\right)$ & $p-\mathrm{MeOC}_{6} \mathrm{H}_{4} \mathrm{Br}$ & 20000 & air & 3 & 83 \\
\hline 20 & $\mathbf{3 b}\left(2 \times 10^{-5}\right)$ & $p-\mathrm{MeCOC}_{6} \mathrm{H}_{4} \mathrm{Br}$ & 100000 & air & 5 & 77 \\
\hline 21 & $\mathbf{3 b}\left(2 \times 10^{-6}\right)$ & $p-\mathrm{MeCOC}_{6} \mathrm{H}_{4} \mathrm{Br}$ & 1000000 & air & 3 & 40 \\
\hline 22 & $\mathbf{3 b}\left(2 \times 10^{-6}\right)$ & $p-\mathrm{MeCOC}_{6} \mathrm{H}_{4} \mathrm{Br}$ & 1000000 & air & 20 & 100 \\
\hline 23 & $\mathbf{3 a}\left(2 \times 10^{-6}\right)$ & $p-\mathrm{MeCOC}_{6} \mathrm{H}_{4} \mathrm{Br}$ & 1000000 & air & 20 & 89 \\
\hline 24 & $\mathbf{5 a}\left(2 \times 10^{-6}\right)$ & $p-\mathrm{MeCOC}_{6} \mathrm{H}_{4} \mathrm{Br}$ & 1000000 & air & 20 & 100 \\
\hline 25 & $\mathbf{5 b}\left(2 \times 10^{-6}\right)$ & $p-\mathrm{MeCOC}_{6} \mathrm{H}_{4} \mathrm{Br}$ & 1000000 & air & 20 & 100 \\
\hline $26^{f}$ & $\mathbf{3 b}\left(1 \times 10^{-4}\right)$ & $p-\mathrm{MeCOC}_{6} \mathrm{H}_{4} \mathrm{Br}$ & 20000 & air & 3 & 100 \\
\hline 27 & $\mathbf{3 a}\left(1 \times 10^{-3}\right)$ & $2,4,6$-tri- $\mathrm{MeC}_{6} \mathrm{H}_{2} \mathrm{Br}$ & 2000 & air & 3 & 76 \\
\hline 28 & $\mathbf{3 b}\left(1 \times 10^{-3}\right)$ & $2,4,6$-tri- $\mathrm{MeC}_{6} \mathrm{H}_{2} \mathrm{Br}$ & 2000 & air & 3 & 69 \\
\hline 29 & $\mathbf{5 b}\left(1 \times 10^{-3}\right)$ & $p-\mathrm{MeOC}_{6} \mathrm{H}_{4} \mathrm{Cl}$ & 2000 & air & 17 & 72 \\
\hline $30^{f}$ & $\mathbf{3 a}\left(2 \times 10^{-4}\right)$ & $p-\mathrm{MeCOC}_{6} \mathrm{H}_{4} \mathrm{Cl}$ & 10000 & air & 1 & 96 \\
\hline 31 & $\mathbf{5 b}\left(2 \times 10^{-5}\right)$ & $p-\mathrm{MeCOC}_{6} \mathrm{H}_{4} \mathrm{Cl}$ & 10000 & air & 3 & 80 \\
\hline
\end{tabular}

${ }^{a}$ Reaction conditions: $\operatorname{ArX}(2 \mathrm{mmol}), \mathrm{PhB}(\mathrm{OH})_{2}(3 \mathrm{mmol})$, catalysts, $\mathrm{K}_{2} \mathrm{CO}_{3}(4 \mathrm{mmol}), \mathrm{EtOH}(5 \mathrm{~mL})$, reflux. ${ }^{b}$ Determined by ${ }^{1} \mathrm{H}$ NMR spetroscopy based on ArX. ${ }^{c}$ At $30{ }^{\circ} \mathrm{C} .{ }^{d} \mathrm{In} \mathrm{DMF} .{ }^{e} \mathrm{In} \mathrm{CH}_{3} \mathrm{OH} .{ }^{f}$ In water and 0.5 equiv of TBAB (tetrabutylammonium bromide) was added.

rable with complex 5b. However, it is noticed that all bond angles around the metal center in $\mathbf{7}$ are much more derivated from square planar than in $\mathbf{5 b}$, due to the fivemembered chelate ring.

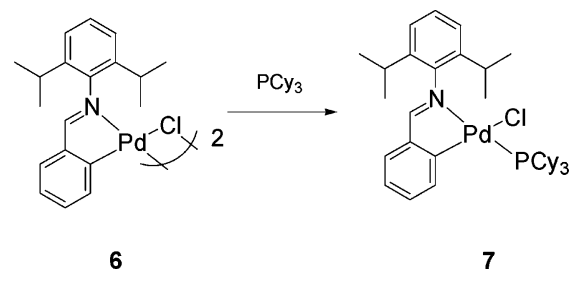

Suzuki-Miyaura Coupling Reaction. All palladacyclic complexes prepared in this work were subjected to an evaluation of their catalytic activities on the coupling reaction of phenylboronic acid with aryl halides. In a typical experiment for the reaction, aryl bromide, phenylboric acid, and $\mathrm{K}_{2} \mathrm{CO}_{3}$ in a ratio of 1:1.5:2 were placed in a flask, followed by the addition of the solvent and the catalyst. In all instances the solvent was used as obtained commercially without further purification, while deionized water was used for aqueous systems. The organic product was isolated by extraction and then analyzed by ${ }^{1} \mathrm{H}$ NMR spectroscopy.

The initial screen on solvents was performed using $\mathbf{3 b}$ as the catalyst precursor (Table 3, entries 5-8). It appeared that the protic solvents including water gave much better results than any other organic solvents. ${ }^{9}$ This coupling reaction running in DMF only provided a moderate yield as compared with alcoholic solvents. This result is quite similar to that reported by Nolan and co-workers using a palladacycle carbene complex in the coupling of aryl chloride with phenylboronic acid. ${ }^{3 \mathrm{~h}}$ It is noticed that the reactions can be carried out under an atmosphere of air. Therefore, the activities of various palladium complexes were screened using ethanol as the solvent under aerobic conditions. Results are summarized in Table 3.

As the molar ratio of [substrate]/[Pd] remains $\sim 20000$, all palladacyclic catalysts show good catalytic activities in Suzuki coupling. Among them, complexes $\mathbf{3 a}$ and $\mathbf{3 b}$ ought to be the best ones, even better than the phosphine-substituted complexes $\mathbf{5 a}-\mathbf{d}$. For $\mathbf{3 a}$ and $\mathbf{3 b}$ it appears that the steric hindrance of the ligand has less influence on the catalysis. However, the yield drops dramatically within a reasonable period of reaction time $(\sim 20 \mathrm{~h})$ when the molar ratio of [substrate]/[Pd] increases up to $10^{6}$ (entries 11, 18), indicating a concentration limitation of these catalysts. Among these studies, we found that the palladacycle with a sixmembered chelate ring, $\mathbf{5 a}-\mathbf{d}$, were slightly better than those with five-membered rings, $\mathbf{6}$. This observation also applies for the phosphine-substituted palladacycles; That is, the catalytic activities of $\mathbf{5 a}-\mathbf{d}$ are better than that of 7 (entries 13-16 versus 19). The catalytic activities of $\mathbf{3 a}, \mathbf{b}$ are generally as good as those for $\mathbf{5 a}-\mathbf{d}$, indicating that phosphine ligands are not necessary in this reaction. It is worthy to mention that the coupling reaction can be carried out at room temperature (entry 4). A quantitative conversion was observed for the coupling of $p$-bromoanisole with phenylboronic acid catalyzed by $\mathbf{3 b}$ in water with the presence of tetraalkylammonium salt (entries 8,26 ).

As for the activated substrate ( $p$-acetylphenyl bromide), the turnover number can reach $10^{6}$ for $\mathbf{3 b}, \mathbf{5 a}$, 


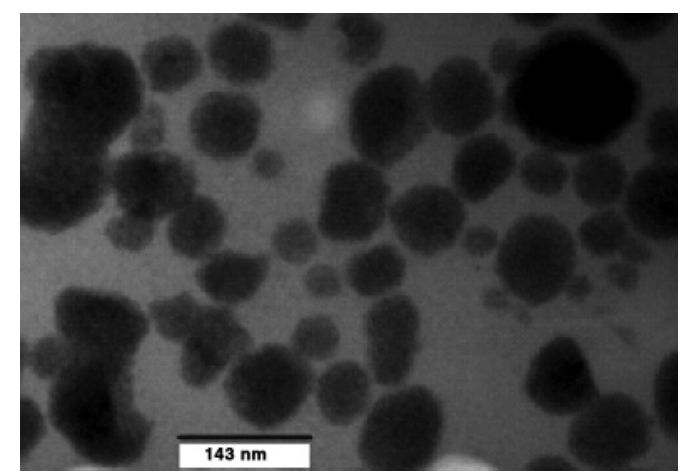

Figure 5. TEM micrograph of palladium nanoparticles generated from the coupling reaction catalyzed by $\mathbf{3 b}$.

and $\mathbf{5 b}$ (entries 22-25). In addition, complexes $\mathbf{3 a}$ and 3b catalyzed the coupling of the sterically bulky substrate such as 2,4,6-( $\mathrm{Me})_{3} \mathrm{C}_{6} \mathrm{H}_{2} \mathrm{Br}$ with phenylboronic acid in good conversions (entries 27, 28).

Under similar reaction conditions, the catalytic activities of these palladacycles toward aryl chloride appear to be lower than the bromo substrates (entry 29). However, the conversion can be improved by carrying out the reaction in water medium and in the presence of tetrabutylammonium salt (entries 30,31$).{ }^{9}$ Overall, the palladium complexes prepared in this work behave with high catalytic acitivity in the Suzuki-Miyaura coupling reaction.

Mechanistic Pathway of Catalysis. To probe the reaction pathway, the course of the coupling reaction was monitored by taking samples and analyzing them by ${ }^{1} \mathrm{H}$ NMR and TEM. First, an aliquot from the reaction of $\mathbf{3 b}$ with phenylboronic acid (2 equiv) in the presence of $\mathrm{K}_{2} \mathrm{CO}_{3}$ and ethanol was examined by transmission electron microscopy, showing the formation of palladium particles with a diameter in the range $50-60 \mathrm{~nm}$ (Figure 5). Upon addition of $p$-bromoanisole to the above solution, the coupling reaction proceeded smoothly to yield $p$-methoxybiphenyl quantitatively, suggesting that the palladium nanoparticles might be the active catalyst for the reaction.

In further studies, we found that complex $\mathbf{3 b}$ readily reacted with ethanol under basic conditions to generate acetaldehyde and the free ligand $\mathbf{4 b}$ accompanied with palladium nanoparticles, but aggregate to produce palladium black without the presence of other substrates. The formation of acetaldehyde is presumably due to the substitution of chloride ligands by ethoxide under basic conditions followed by $\beta$-elimination. ${ }^{\text {hh }}$ Addition of phenylboronic acid to the above solution yielded benzene and biphenyl immediately (Table 4). On the other hand, $p$-acetophenyl bromide was converted into acetophenone and 4,4'-bisacetobiphenyl, as evidenced by ${ }^{1} \mathrm{H}$ NMR spectroscopy. However, the reaction of $p$-acetophenyl chloride was much slower than that of bromide (Table 4 , entry 2). The production of biphenyl derivatives and the reduced compounds is presumably via the addition of phenylboronic acid or $p$-acetophenyl bromide to the palladium nanoparticles followed by reductive elimination (Scheme 2). We also found that the decomposition rate of aryl bromide is much slower than that of arylboronic acid, revealing that the oxidative addition of aryl halide to the metal is the rate-limiting step in the cross-coupling reaction. This also explains that the use of excess arylboronic acid in the Suzuki-Miyaura reactions is generally required for better conversions. It should be mentioned that the reduction of aryl halides or arylboronic acid proceeded superiorly than that of the homo-coupling reaction.

The decomposition rate of palladcycles in basic ethanol solution follows the order $\mathbf{6}>\mathbf{3 b}>\mathbf{5 b}>\mathbf{5 d}$ (Table 5). Complex 6 appeared to be slower than $\mathbf{3 b}$, but aggregated into larger nanoparticles (100-200 nm), which explained the activity difference between $\mathbf{6}$ and 3b due to the size effect. ${ }^{11}$ As for the phosphinesubstituted complexes $\mathbf{5 b}$ and $\mathbf{5 d}$, the decomposition was much slower than that of $\mathbf{3} \mathbf{b}$ presumably due to the stabilization of the coordinating phosphine. Another finding is that the surfactant-stabilized palladium nanoparticles appear to be less active than those generated in situ. In the presence of tetrabutylammonium bromide, palladium nanoparticles was obtained from the decomposition of complex $\mathbf{3 b}$ in ethanol. The resulting palladium nanoparticles were used as the catalyst for the coupling reaction of $\mathrm{PhB}(\mathrm{OH})_{2}$ and $\mathrm{MeOC}_{6} \mathrm{H}_{4} \mathrm{Br}$ to give the desired product but in a slower conversion rate by ca. $20 \%$.

It has been demonstrated that palladium nanoparticles can catalyze the $\mathrm{C}-\mathrm{C}$ bond coupling reaction, ${ }^{12}$ particularly under Jeffery condition for Heck reaction. ${ }^{13}$ Unlike the palladium clusters stabilized by tetraalkylammonium salt, the nanoparticles generated from the reduction of palladacycles are presumably surrounded by the imine ligands, which tend to aggregate with the precipitation of palladium black. This reveals the weak stabilizing effect of these ligands toward nanoparticles. On the other hand, the loose protection makes these palladium particles highly active toward the substrates. ${ }^{12}$

Furthermore, the low concentrations of palladium complexes may also prevent the rapid formation of palladium black and the formation of larger nanoparticles, suggesting the extreme activity of metal clusters. However, the conversion decreases when the ratio [substrate]/[Pd] is higher than $10^{6}$ (Table 3 entries 3 , 11), showing a limitation of these nanoparticles in catalysis.

\section{Summary}

We have synthesized and characterized a new series of air-stable palladacycles. These palladium complexes were successfully applied in the Suzuki-Miyaura coupling reaction and had good catalytic activities, for example, the turnover frequency of up to $10^{7} \mathrm{~mol} / \mathrm{mol}-$ $(\mathrm{Pd}) \cdot \mathrm{h}$ for $\mathbf{3 b}$ in the coupling of $p$-bromoanisole or $p$-bromoacetophenone with phenylboronic acid. Notable were the reaction conditions employed, i.e., the moisture and air insensitivity. Several observations confirm that the Suzuki-Miyaura coupling catalyzed by palladcyclic complexes is via the palladium nanoparticles. Reactions of $p$-bromoacetophenone or arylboronic acid individually on the nanoparticles leading to homo-coupled and reduced products were investigated, but the cross-

(11) Narayanan, R.; El-Sayed, M. A. J. Phys. Chem. B 2004, 108 8572 .

(12) For a recent review see: Reetz, M. T.; de Vries, J. G. Chem Commun. 2004, 1959.

(13) Jeffery, T. J. Chem. Soc., Chem. Commun. 1984, 1287. 
Table 4. Decomposition of Aryl Halides or Arylboronic Acids on Palladium Nanopartices Generated in Situ from Palladacyclic Complexes ${ }^{a}$

\begin{tabular}{clccrrr}
\hline entry & \multicolumn{1}{c}{ substrate } & complex & conditions & time & conversion & reduced product:coupling product (ratio $)^{b}$ \\
\hline 1 & $p-\mathrm{MeCOC}_{6} \mathrm{H}_{4} \mathrm{Br}$ & $\mathbf{3 b}$ & reflux & $2 \mathrm{~h}$ & $100 \%$ & $\mathrm{MeCOC}_{6} \mathrm{H}_{5}(63):\left(p-\mathrm{MeCOC}_{6} \mathrm{H}_{4}\right)_{2}(37)$ \\
2 & $p-\mathrm{MeCOC}_{6} \mathrm{H}_{4} \mathrm{Cl}$ & $\mathbf{3 b}$ & reflux & $10 \mathrm{~h}$ & $46 \%$ & $\mathrm{MeCOC}_{6} \mathrm{H}_{5}(67):\left(p-\mathrm{MeCOC}_{6} \mathrm{H}_{4}\right)_{2}(33)$ \\
3 & $p-\mathrm{MeCOC}_{6} \mathrm{H}_{4} \mathrm{Br}$ & $\mathbf{6}$ & reflux & $2 \mathrm{~h}$ & $77 \%$ & $\mathrm{MeCOC}_{6} \mathrm{H}_{5}(80):\left(p-\mathrm{MeCOC}_{6} \mathrm{H}_{4}\right)_{2}(20)$ \\
4 & $p-\mathrm{MeCOC}_{6} \mathrm{H}_{4} \mathrm{Br}$ & $\mathbf{5 b}$ & reflux & $2 \mathrm{~h}$ & $100 \%$ & $\mathrm{MeCOC}_{6} \mathrm{H}_{5}(100):\left(p-\mathrm{MeCOC}_{6} \mathrm{H}_{4}\right)_{2}(0)$ \\
5 & $\mathrm{PhB}(\mathrm{OH})_{2}$ & $\mathbf{3 b}$ & reflux & $1 \mathrm{~h}$ & $100 \%$ & $\mathrm{C}_{6} \mathrm{H}_{6}(98): \mathrm{C}_{6} \mathrm{H}_{5}-\mathrm{C}_{6} \mathrm{H}_{5}(2)$ \\
6 & $\mathrm{PhB}(\mathrm{OH})_{2}$ & $\mathbf{3 b}$ & $40{ }^{\circ} \mathrm{C}$ & $8 \mathrm{~h}$ & $100 \%$ & $\mathrm{C}_{6} \mathrm{H}_{6}(91): \mathrm{C}_{6} \mathrm{H}_{5}-\mathrm{C}_{6} \mathrm{H}_{5}(9)$ \\
7 & $p-\mathrm{MeOC}_{6} \mathrm{H}_{4} \mathrm{~B}(\mathrm{OH})_{2}$ & $\mathbf{3 b}$ & $40{ }^{\circ} \mathrm{C}$ & $8 \mathrm{~h}$ & $100 \%$ & $\mathrm{MeOC}_{6} \mathrm{H}_{5}(98):\left(p-\mathrm{MeOC}_{6} \mathrm{H}_{4}\right)_{2}(2)$ \\
8 & $p-\mathrm{MeC}_{6} \mathrm{H}_{4} \mathrm{~B}(\mathrm{OH})_{2}$ & $\mathbf{3 b}$ & $40{ }^{\circ} \mathrm{C}$ & $8 \mathrm{~h}$ & $100 \%$ & $\mathrm{MeC}_{6} \mathrm{H}_{5}(98):\left(p-\mathrm{MeC}_{6} \mathrm{H}_{4}\right)_{2}(2)$
\end{tabular}

${ }^{a}$ Conditions: Aryl halides $(1 \mathrm{mmol})$ [or $\left.\mathrm{ArB}(\mathrm{OH})_{2}(0.5 \mathrm{mmol})\right], \mathrm{K}_{2} \mathrm{CO}_{3}(2 \mathrm{mmol})$, and $\mathrm{Pd}$ complex $(\mathrm{mmol})$ in EtOH $(2 \mathrm{~mL}) .{ }^{b} \mathrm{Ratio}$ is determined by ${ }^{1} \mathrm{H}$ NMR integration and is given in parentheses.

Scheme 2

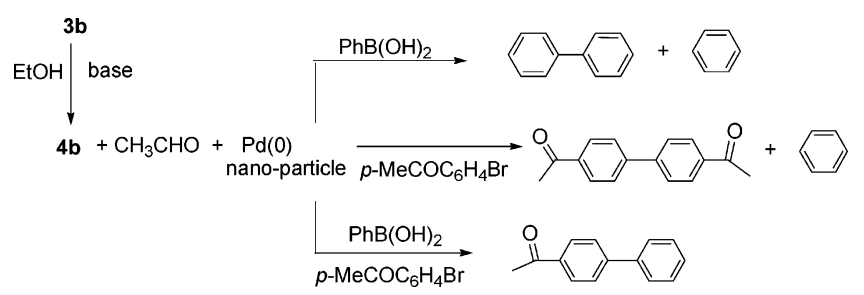

Table 5. Relative Decomposition Rate of Palladcycle in Basic Etahanol Solution ${ }^{a}$

\begin{tabular}{|c|c|c|c|c|}
\hline & $\mathbf{3 a}$ & $\mathbf{3 b}$ & $5 b$ & $5 d$ \\
\hline$\%$ of decomposition ${ }^{b}$ & $40 \%$ & $70 \%$ & $14 \%$ & trace \\
\hline
\end{tabular}

${ }^{a}$ A solution of complex $\left(2 \times 10^{-2} \mathrm{mmol}\right)$ and $\mathrm{K}_{2} \mathrm{CO}_{3}\left(2 \times 10^{-1}\right.$ $\mathrm{mmol})$ in ethanol $(2 \mathrm{~mL})$ was stirred at $40{ }^{\circ} \mathrm{C}$ for $30 \mathrm{~min} .{ }^{b}$ Percent of decomposition was determined by ${ }^{1} \mathrm{H}$ NMR spectroscopy.

coupled ones were obtained when the aryl halide and arylboronic acid were present. However, the pathway for the cross-coupling and reduction processes on these particles remains unclear. More work is necessary in order to work out the nature of these nanoparticles.

\section{Experimental Section}

General Information. All reactions, manipulations, and purifications steps were performed under a dry nitrogen atmosphere. Tetrahydrofuran was distilled under nitrogen from sodium benzophenone ketyl. Dichloromethane and acetonitrile were dried with $\mathrm{CaH}_{2}$ and distilled under nitrogen. Other chemicals and solvents were of analytical grade and were used as received unless otherwise stated.

Nuclear magnetic resonance spectra were recorded in $\mathrm{CDCl}_{3}$ on either a Bruker AM-300 or AVANCE-400 spectrometer. Chemical shifts are given in parts per million relative to $\mathrm{Me}_{4} \mathrm{~S}$ for ${ }^{1} \mathrm{H}$ and relative to $85 \% \mathrm{H}_{3} \mathrm{PO}_{4}$ for ${ }^{31} \mathrm{P} \mathrm{NMR}$. Infrared spectra were measured on a Perkin-Elmer 983G spectrometer (SeriesII) as $\mathrm{KBr}$ pellets, unless otherwise noted. Preparation of 6 followed the procedures published previously. ${ }^{14}$

General Procedure for Preparation of Schiff Base Ligands 4a,b. A methanol $(15 \mathrm{~mL})$ solution of the substituted benzylaldehyde $(10 \mathrm{mmol})$ and the substituted aniline $(10 \mathrm{mmol})$ was added into a single-necked round-bottomed flask equipped with a condenser. The reaction mixture was stirred at reflux temperature for $24 \mathrm{~h}$. After the completion of the reaction, the yellow crystal product was precipitated upon cooling. The solid product was filtered, washed with the precooled hexane, and dried, whereas the liquid compound $\mathbf{1 b}$ was purified by distilling off the starting aldehyde and chromatographed on silica gel with elution of hexane.

(14) Chen, C.-L.; Liu, Y.-H.; Peng, S.-M.; Liu, S.-T. J. Organomet. Chem. 2004, 689, 1806.
(2,6-Dimethylphenyl) (2,4,6-trimethylbenezylidene)amine, 4a: yellow liquid $(90 \%)$; IR $(\mathrm{KBr}) 1625 \mathrm{~cm}^{-1}\left(v_{\mathrm{C}=\mathrm{N}}\right)$; ${ }^{1} \mathrm{H}$ NMR $\left(\mathrm{CDCl}_{3}, 400 \mathrm{MHz}\right) \delta 8.68(\mathrm{~s}, 1 \mathrm{H},-\mathrm{HC}=\mathrm{N}), 7.15(\mathrm{~s}$ $2 \mathrm{H}, \mathrm{Ar} H), 7.04-6.95(\mathrm{~m}, 3 \mathrm{H}, \mathrm{Ar} H), 2.66$ (s, 6H, $-M e), 2.40$ $(\mathrm{s}, 3 \mathrm{H},-M e), 2.28(\mathrm{~s}, 6 \mathrm{H},-\mathrm{Me}) ;{ }^{13} \mathrm{C} \mathrm{NMR} \delta 163.0,152.6,139.9$, $138.8,130.0,129.9,128.1,126.7,123.4,21.3,21.1,18.8 ; \mathrm{FAB}$ $m / z 251.1\left(\mathrm{M}^{+}\right)$. Anal. Calcd for $\mathrm{C}_{18} \mathrm{H}_{21} \mathrm{~N}: \mathrm{C}, 86.01 ; \mathrm{H}, 8.42 ; \mathrm{N}$, 5.57. Found: C, 86.11; H, 8.65; N, 5.55.

(2,6-Diisopropylphenyl)(2,4,6-trimethylbenzylidene)amine, 4b: white solids $(91 \%)$; mp $99-101{ }^{\circ} \mathrm{C}$; IR $(\mathrm{KBr})$ $1627 \mathrm{~cm}^{-1}\left(v_{\mathrm{C}=\mathrm{N}}\right) ;{ }^{1} \mathrm{H} \mathrm{NMR}\left(\mathrm{CDCl}_{3}, 400 \mathrm{MHz}\right) \delta 8.64(\mathrm{~s}, 1 \mathrm{H}$, $-H \mathrm{C}=\mathrm{N}), 7.24-7.22(\mathrm{~m}, 2 \mathrm{H}, \operatorname{Ar} H), 7.17-7.15(\mathrm{~m}, 1 \mathrm{H}, \operatorname{Ar} H)$, 7.01 (s, $1 \mathrm{H}, \mathrm{Ar} H$ ); 3.12 (sept., $J=6.8 \mathrm{~Hz}, 2 \mathrm{H},-\mathrm{CH}), 2.65$ (s, $6 \mathrm{H},-M e), 2.39(\mathrm{~s}, 3 \mathrm{H},-M e), 1.25(\mathrm{~d}, J=6.8 \mathrm{~Hz}, 12 \mathrm{H},-M e)$; ${ }^{13} \mathrm{C}$ NMR $\delta 162.3,150.5,140.1,139.2,137.4,130.2,129.7$, 123.8, 122.9, 27.8, 23.7, 21.5, 21.1; FAB $\mathrm{m} / z 307.2\left(\mathrm{M}^{+}\right)$. Anal. Calcd for $\mathrm{C}_{22} \mathrm{H}_{29} \mathrm{~N}$ : C, 85.94; H, 9.51; N, 4.56. Found: C, 86.24; H, 9.64; N, 4.57.

General Procedure for Preparation of Palladacycle Complexes 3a,b. To a round-bottomed flask with a stir bar was placed palladium dichloride $(118 \mathrm{mg}, 0.67 \mathrm{mmol})$ under nitrogen. Predried acetonitrile $(10 \mathrm{~mL})$ was added, and the resulting mixture was stirred at room temperature. The mixture turned yellow immediately. After stirring for 2 days, the solvent was removed to dryness. Then ligand $(0.71 \mathrm{mmol})$, excess sodium acetate $(110 \mathrm{mg}, 10.4 \mathrm{mmol})$, and tetrahydrofuran $(15 \mathrm{~mL})$ were added. The reaction mixture was stirred at room temperature for another $38 \mathrm{~h}$. After removal of solvents, dichloromethane $(20 \mathrm{~mL})$ was added and the solution was filtered through Celite. The filtrate was concentrated, and the residue was washed with hexane $(10 \mathrm{~mL} \times 3)$ to give the desired product.

Complex 3a: brown solids (80\%); $\mathrm{mp} 252{ }^{\circ} \mathrm{C}$ (dec); IR (KBr) $1600 \mathrm{~cm}^{-1}\left(v_{\mathrm{C}=\mathrm{N}}\right) ;{ }^{1} \mathrm{H} \mathrm{NMR}\left(\mathrm{CDCl}_{3}, 400 \mathrm{MHz}\right) \delta 7.77(\mathrm{~s}, 1 \mathrm{H}$, $-H \mathrm{C}=\mathrm{N}), 7.07-7.01(\mathrm{~m}, 4 \mathrm{H}, \mathrm{Ar} H), 6.80(\mathrm{~s}, 1 \mathrm{H}, \mathrm{Ar} H), 3.19$ $\left(\mathrm{s}, 2 \mathrm{H},-\mathrm{H}_{2} \mathrm{C}-\mathrm{Pd}\right), 2.41(\mathrm{~s}, 6 \mathrm{H},-\mathrm{Me}), 2.28(\mathrm{~s}, 3 \mathrm{H},-M e), 2.27$ $(\mathrm{s}, 3 \mathrm{H},-\mathrm{Me}) ;{ }^{13} \mathrm{C} \mathrm{NMR} \delta 163.1,150.2,145.8,143.8,139.5$, $130.9,130.0,128.2,127.6,126.2,125.3,23.3,21.4,19.5,18.9$; FAB $m / z 749.0\left(\mathrm{M}^{+}-\mathrm{Cl}^{-}\right)$. Anal. Calcd for $\mathrm{C}_{36} \mathrm{H}_{40} \mathrm{Cl}_{2} \mathrm{~N}_{2} \mathrm{Pd}_{2}$ : C, 55.12; H, 5.14; N, 3.57. Found: C, 55.34; H, 5.04; N, 3.44.

Complex 3b: orange solids $(90 \%) ; \mathrm{mp} 270{ }^{\circ} \mathrm{C}$ (dec); IR (KBr) $1599 \mathrm{~cm}^{-1}\left(v_{\mathrm{C}=\mathrm{N}}\right) ;{ }^{1} \mathrm{H} \mathrm{NMR}\left(\mathrm{CDCl}_{3}, 400 \mathrm{MHz}\right) \delta 7.81(\mathrm{~s}, 1 \mathrm{H}$, $-H \mathrm{C}=\mathrm{N}), 7.23(\mathrm{t}, J=7.3 \mathrm{~Hz}, 1 \mathrm{H}, \operatorname{Ar} H), 7.14(\mathrm{~d}, J=7.3 \mathrm{~Hz}$, $2 \mathrm{H}, \operatorname{Ar} H), 6.98$ (s, 1H, Ar H), 6.82 (s, 1H, Ar H), 3.48-3.39 $(\mathrm{m}, 2 \mathrm{H},-\mathrm{CH}), 3.24\left(\mathrm{~s}, 2 \mathrm{H},-\mathrm{H}_{2} \mathrm{C}-\mathrm{Pd}\right), 2.30(\mathrm{~s}, 3 \mathrm{H},-M e), 2.29$ $(\mathrm{s}, 3 \mathrm{H},-M e), 1.47(\mathrm{~d}, J=6.7 \mathrm{~Hz}, 6 \mathrm{H},-M e), 1.11(\mathrm{~d}, J=6.8$ $\mathrm{Hz}, 6 \mathrm{H},-M e) ;{ }^{13} \mathrm{C}$ NMR $\delta 162.7,148.0,146.5,143.7,140.7$, $139.8,130.6,127.6,126.8,125.4,123.3,28.2,24.8,23.2$, 22.5, 21.4, 19.1; FAB $\mathrm{m} / z$ 861.1 $\left(\mathrm{M}^{+}-\mathrm{Cl}^{-}\right)$. Anal. Calcd for $\mathrm{C}_{44} \mathrm{H}_{56} \mathrm{Cl}_{2} \mathrm{~N}_{2} \mathrm{Pd}_{2}$ : C, 58.94; $\mathrm{H}, 6.29 ; \mathrm{N}, 3.12$. Found: $\mathrm{C}, 58.89$; H, 6.35; N, 3.08.

General Procedure for Preparation of PhosphineSubstituted Palladacycle Complexes. To a degassed flask loaded with the palladacycle dimer complex $(1 \mathrm{mmol})$ and dichloromethane $(5 \mathrm{~mL})$ was added phosphine $(2 \mathrm{mmol})$. Upon stirring at room temperature for $2 \mathrm{~h}$, the solvent of the reaction 
Table 6. Crystallographic Data of $3 a, 5 b, 5 d$, and 7

\begin{tabular}{|c|c|c|c|c|}
\hline & $\mathbf{3 a}$ & $\mathbf{5 b}$ & $5 d$ & 7 \\
\hline formula & $\mathrm{C}_{36} \mathrm{H}_{40} \mathrm{Cl}_{2} \mathrm{~N}_{2} \mathrm{Pd}_{2}$ & $\mathrm{C}_{40} \mathrm{H}_{61} \mathrm{ClNPPd}$ & $\mathrm{C}_{40} \mathrm{H}_{43} \mathrm{ClNPPd}$ & $\mathrm{C}_{37} \mathrm{H}_{55} \mathrm{ClNPPd}$ \\
\hline fw & 784.40 & 728.72 & 710.57 & 686.64 \\
\hline cryst syst & monoclinic & orthorhombic & monoclinic & monoclinic \\
\hline space group & $P 2_{1} / c$ & Pbca & $P 2_{1} / c$ & $P 2_{1} / n$ \\
\hline$a, \AA$ & $12.7010(1)$ & $19.3320(2)$ & $17.0000(3)$ & $11.7670(1)$ \\
\hline$b, \AA$ & $8.794(1)$ & 17.372092) & $11.6040(2)$ & $17.0560(1)$ \\
\hline$c, \AA$ & $15.7000(2)$ & $22.6590(2)$ & $18.4260(3)$ & $18.4730(2)$ \\
\hline$\alpha, \operatorname{deg}$ & 90 & 90 & 90 & 90 \\
\hline$\beta, \operatorname{deg}$ & $103.978(1)$ & 90 & $104.528(1)$ & $105.267(1)$ \\
\hline$\gamma, \operatorname{deg}$ & 90 & 90 & 90 & 90 \\
\hline$V, \AA^{\circ}$ & $1701.65(3)$ & $7609.7(1)$ & $3518.6(1)$ & $3576.65(5)$ \\
\hline$Z$ & 2 & 8 & 4 & 4 \\
\hline$D_{\text {calcd }}, \mathrm{Mg} / \mathrm{m}^{3}$ & 1.531 & 1.272 & 1.341 & 1.275 \\
\hline$F(000)$ & 792 & 3088 & 1472 & 1448 \\
\hline cryst size, mm & $0.25 \times 0.20 \times 0.15$ & $0.30 \times 0.25 \times 0.15$ & $0.25 \times 0.20 \times 0.15$ & $0.30 \times 0.20 \times 0.15$ \\
\hline$\theta$ range & $1.65-25.00$ & $1.80-27.48$ & $2.09-27.47$ & $1.65-27.47$ \\
\hline no. of reflns collected & 9728 & 50044 & 25239 & 26619 \\
\hline no. of indep reflns & $3006\left(R_{\text {int }}=0.0286\right)$ & $8719\left(R_{\text {int }}=0.0467\right)$ & $8026\left(R_{\text {int }}=0.0367\right)$ & $8175\left(R_{\text {int }}=0.0336\right)$ \\
\hline$R[I>2 \sigma(I)]$ & $\begin{array}{l}R_{1}=0.0302 \\
w R_{2}=0.0803\end{array}$ & $\begin{array}{l}R_{1}=0.0474 \\
w R_{2}=0.1219\end{array}$ & $\begin{array}{l}R_{1}=0.0404 \\
w R_{2}=0.0973\end{array}$ & $\begin{array}{l}R_{1}=0.0402 \\
w R_{2}=01069\end{array}$ \\
\hline goodness-of-fit on $F^{2}$ & $\begin{array}{l}\text { wn: } \\
1.187\end{array}$ & 1.111 & $\begin{array}{l}\text { wn } 2-0.0910 \\
1.173\end{array}$ & 1.122 \\
\hline
\end{tabular}

mixture was evaporated. The residue was crystallized in dichloromethane/ether to give the desired complex in crystalline solids.

Complex 5a: yellow solids (99\%); IR ( $\mathrm{KBr}) 1607 \mathrm{~cm}^{-1}$ $\left(v_{\mathrm{C}=\mathrm{N}}\right) ;{ }^{1} \mathrm{H} \mathrm{NMR}\left(\mathrm{CDCl}_{3}, 300 \mathrm{MHz}\right) \delta 8.06(\mathrm{~d}, J=11.0 \mathrm{~Hz}, 1 \mathrm{H}$, $-H \mathrm{C}=\mathrm{N}), 7.07-7.00(\mathrm{~m}, 3 \mathrm{H}, \mathrm{Ar} H), 6.89(\mathrm{~s}, 1 \mathrm{H}, \operatorname{Ar} H), 6.76$ $(\mathrm{s}, 1 \mathrm{H}, \operatorname{Ar} H), 2.90\left(\mathrm{~s}, 2 \mathrm{H},-\mathrm{H}_{2} \mathrm{C}-\mathrm{Pd}\right), 2.53(\mathrm{~s}, 6 \mathrm{H},-\mathrm{Me}), 2.34$ $(\mathrm{s}, 3 \mathrm{H},-\mathrm{Me}), 2.36-2.26\left(\mathrm{~m}, 3 \mathrm{H}, \mathrm{PCy}_{3}\right), 1.94-1.42(\mathrm{~m}, 21 \mathrm{H}$, $\left.\mathrm{PCy}_{3}\right), 1.28-1.22\left(\mathrm{~m}, 9 \mathrm{H}, \mathrm{PCy}_{3}\right) ;{ }^{13} \mathrm{C} \mathrm{NMR}\left(\mathrm{CDCl}_{3}, 100 \mathrm{MHz}\right)$ $\delta$ 163.3, 151.3, 146.7, 142.5, 139.5, 130.9 139.9, 127.9, 127.4, $126.2,125.6,33.4\left(\mathrm{~d}, J_{C-P}=22 \mathrm{~Hz}\right), 29.8,27.7\left(\mathrm{~d}, J_{C-P}=10.9\right.$ $\mathrm{Hz}), 26.6,22.4,21.3,20.4,18.9 ;{ }^{31} \mathrm{P} \mathrm{NMR}\left(\mathrm{CDCl}_{3}, 161.9 \mathrm{MHz}\right)$ 39.8. Anal. Calcd for $\mathrm{C}_{36} \mathrm{H}_{35}$ ClNPPd: C, 64.28; H, 7.94; N, 2.08 . Found: C, 63.97; H, 7.65; N, 1.80.

Complex 5b: yellow solids (99\%); IR (KBr) $1603 \mathrm{~cm}^{-1}$ $\left(v_{\mathrm{C}=\mathrm{N}}\right) ;{ }^{1} \mathrm{H} \mathrm{NMR}\left(\mathrm{CDCl}_{3}, 400 \mathrm{MHz}\right) \delta 8.03\left(\mathrm{~d}, J_{H-P}=10.9 \mathrm{~Hz}\right.$, $-H \mathrm{C}=\mathrm{N}), 7.20(\mathrm{bs}, 3 \mathrm{H}, \mathrm{Ar} H), 6.92(\mathrm{~s}, 1 \mathrm{H}, \operatorname{Ar} H), 6.80(\mathrm{~s}, 1 \mathrm{H}$, Ar $H), 3.85-3.78(\mathrm{~m}, 2 \mathrm{H},-\mathrm{CH}), 2.92(\mathrm{~d}, J=2.4 \mathrm{~Hz}, 2 \mathrm{H}$, $-\mathrm{H}_{2} \mathrm{C}-\mathrm{Pd}$ ), 2.37 (s, 3H, $-\mathrm{Me}$ ), 2.37-2.30 (m, 3H, $\left.\mathrm{PCy}_{3}\right), 2.30$ $(\mathrm{s}, 3 \mathrm{H},-\mathrm{Me}), 1.96-1.94\left(\mathrm{~m}, 6 \mathrm{H}, \mathrm{PCy}_{3}\right) 1.71-1.50(\mathrm{~m}, 15 \mathrm{H}$, $\left.\mathrm{PCy}_{3}\right) 1.46(\mathrm{~d}, J=6.5 \mathrm{~Hz}, 6 \mathrm{H},-M e), 1.30-1.26\left(\mathrm{~m}, 9 \mathrm{H}, \mathrm{PCy}_{3}\right)$, $1.21(\mathrm{~d}, J=6.6 \mathrm{~Hz}, 6 \mathrm{H},-\mathrm{Me}) ;{ }^{13} \mathrm{C} \mathrm{NMR}\left(\mathrm{CDCl}_{3}, 100 \mathrm{MHz}\right) \delta$ $163.1,148.7,146.8,142.5,140.8,139.6,131.1,127.4,126.5$, $126.2,123.1,33.6\left(\mathrm{~d}, J_{C-P}=22.4 \mathrm{~Hz}\right), 29.8,28.5,27.6\left(\mathrm{~d}, J_{C-P}\right.$ $=10.9 \mathrm{~Hz}), 26.4,25.2,23.6,21.6,21.3,19.4 ;{ }^{31} \mathrm{P} \mathrm{NMR}\left(\mathrm{CDCl}_{3}\right.$, $161.9 \mathrm{MHz}$ ) 40.3. Anal. Calcd for $\mathrm{C}_{40} \mathrm{H}_{61}$ ClNPPd: C, 65.92; $\mathrm{H}$, 8.44; N, 1.92. Found: C, 65.86; H, 8.59; N, 1.83

Complex 5c: yellow solids (99\%); IR (KBr) $1602 \mathrm{~cm}^{-1}$ $\left(v_{\mathrm{C}=\mathrm{N}}\right) ;{ }^{1} \mathrm{H} \mathrm{NMR}\left(\mathrm{CDCl}_{3}, 300 \mathrm{MHz}\right) \delta 8.09(\mathrm{~d}, J=12.3 \mathrm{~Hz}, 1 \mathrm{H}$, $-H \mathrm{C}=\mathrm{N}), 7.62-7.56(\mathrm{~m}, 6 \mathrm{H}, \mathrm{Ar} H), 7.42-7.32(\mathrm{~m}, 9 \mathrm{H}, \mathrm{Ar} H)$, 7.11-7.04 (m, 3H, Ar H), 6.71 (s, 1H, Ar H), $5.72(\mathrm{~s}, 1 \mathrm{H}, \mathrm{Ar}$ $H), 2.81\left(\mathrm{~d}, J=5.1 \mathrm{~Hz}, 2 \mathrm{H},-H_{2} \mathrm{C}-\mathrm{Pd}\right), 2.57(\mathrm{~s}, 6 \mathrm{H},-M e)$, $2.33(\mathrm{~s}, 3 \mathrm{H},-\mathrm{Me}), 2.10(\mathrm{~s}, 3 \mathrm{H},-\mathrm{Me}) ;{ }^{31} \mathrm{P} \mathrm{NMR}\left(\mathrm{CDCl}_{3}, 161.9\right.$ $\mathrm{MHz}) \delta$ 36.4. Anal. Calcd for $\mathrm{C}_{36} \mathrm{H}_{35}$ ClNPPd: C, 66.06; H, 5.39; N, 2.14. Found: C, 66.29; H, 5.39; N, 1.68 .

Complex 5d: yellow solids (99\%); IR (KBr) $1600 \mathrm{~cm}^{-1}$ $\left(v_{\mathrm{C}=\mathrm{N}}\right) ;{ }^{1} \mathrm{H} \mathrm{NMR}\left(\mathrm{CDCl}_{3}, 400 \mathrm{MHz}\right) \delta 8.08\left(\mathrm{~d}, J_{H-P}=12 \mathrm{~Hz}\right.$, $-\mathrm{HC}=\mathrm{N}), 7.67-7.60(\mathrm{~m}, 6 \mathrm{H}, \mathrm{Ar} \mathrm{H}), 7.45-7.37$ (m, 9H, Ar H), 7.24 (bs, 3H, Ar H), 6.75 (s, 1H, Ar H), 5.73 (s, 1H, Ar H), $3.85-3.78(\mathrm{~m}, 2 \mathrm{H},-\mathrm{CH}), 2.83\left(\mathrm{~d}, \mathrm{~J}=5.1 \mathrm{~Hz}, 2 \mathrm{H},-\mathrm{H}_{2} \mathrm{C}-\mathrm{Pd}\right)$, $2.36(\mathrm{~s}, 6 \mathrm{H},-\mathrm{Me}), 2.14(\mathrm{~s}, 3 \mathrm{H},-\mathrm{Me}), 2.10(\mathrm{~s}, 3 \mathrm{H},-\mathrm{Me}), 1.5$ $(\mathrm{d}, J=6.7 \mathrm{~Hz}, 6 \mathrm{H},-\mathrm{Me}), 1.28(\mathrm{~d}, J=6.8 \mathrm{~Hz}, 6 \mathrm{H},-\mathrm{Me}) ;{ }^{13} \mathrm{C}$ $\mathrm{NMR}\left(\mathrm{CDCl}_{3}, 100 \mathrm{MHz}\right) \delta 163.6,148.0,144.7$ (d, $J_{C-P}=2.3$ $\mathrm{Hz}), 142.4,140.8,139.3,134.6$ (d, $\left.J_{C-P}=11.4 \mathrm{~Hz}\right), 131.5,131.0$ $\left(\mathrm{d}, J_{C-P}=48.6 \mathrm{~Hz}\right), 130.1\left(\mathrm{~d}, J_{C-P}=2.3 \mathrm{~Hz}\right), 128.0\left(\mathrm{~d}, J_{C-P}=\right.$ $10.5 \mathrm{~Hz}), 127.5,126.5,126.4,123.3,28.6,27.9,25.2,23.7,21.2$, $19.3 ;{ }^{31} \mathrm{P} \mathrm{NMR}\left(\mathrm{CDCl}_{3}, 161.9 \mathrm{MHz}\right) \delta 37.7$. Anal. Calcd for $\mathrm{C}_{40} \mathrm{H}_{43}$ ClNPPd: C, 67.61; H, 6.10; N, 1.97. Found: C, 67.79; $\mathrm{H}, 5.97 ; \mathrm{N}, 1.53$.
Complex 7: yellow solids $99 \%$; IR $(\mathrm{KBr}) 1617 \mathrm{~cm}^{-1}\left(v_{\mathrm{C}=\mathrm{N}}\right)$; ${ }^{1} \mathrm{H} \mathrm{NMR}\left(\mathrm{CDCl}_{3}, 400 \mathrm{MHz}\right) \delta 7.98\left(\mathrm{~d}, J_{\mathrm{H}-\mathrm{P}}=6.8 \mathrm{~Hz}, 1 \mathrm{H}\right.$, $-\mathrm{HC}=\mathrm{N}), 7.42(\mathrm{dd}, J=7.5 \mathrm{~Hz}, J=2.3 \mathrm{~Hz}, 1 \mathrm{H}, \mathrm{Ar} \mathrm{H}), 7.37$ (dd, $J=7.1 \mathrm{~Hz}, J=1.9 \mathrm{~Hz} 1 \mathrm{H}, \mathrm{Ar} \mathrm{H}), 7.19-7.10$ (m, $5 \mathrm{H}, \mathrm{Ar}$ $\mathrm{H}$ ), 3.34 (hept, $J=6.8 \mathrm{~Hz} 2 \mathrm{H},-\mathrm{CH}), 1.30$ (d, $J=6.8 \mathrm{~Hz}, 6 \mathrm{H}$, $-\mathrm{Me}), 1.12(\mathrm{~d}, J=6.8 \mathrm{~Hz}, 6 \mathrm{H},-\mathrm{Me}) ;{ }^{13} \mathrm{C} \mathrm{NMR}\left(\mathrm{CDCl}_{3}, 100\right.$ $\mathrm{MHz}) \delta 176.1\left(\mathrm{~d}, J_{\mathrm{C}-\mathrm{P}}=3.4 \mathrm{~Hz}\right), 159.0,148.2,145.6,141.0$, $137.4\left(\mathrm{~d}, J_{\mathrm{C}-\mathrm{P}}=5.1 \mathrm{~Hz}\right), 130.7\left(\mathrm{~d}, J_{\mathrm{C}-\mathrm{P}}=3.4 \mathrm{~Hz}\right), 129.1,126.3$, $124.1,122.6,34.1\left(\mathrm{~d}, J_{\mathrm{C}-\mathrm{P}}=21.7 \mathrm{~Hz}\right), 30.4,28.4,27.7\left(\mathrm{~d}, J_{\mathrm{C}-\mathrm{P}}\right.$ $=10.9 \mathrm{~Hz}), 26.4,24.6,22.9 ;{ }^{31} \mathrm{P} \mathrm{NMR}\left(\mathrm{CDCl}_{3}, 161.9 \mathrm{MHz}\right) 43.1$. Anal. Calcd for $\mathrm{C}_{37} \mathrm{H}_{55} \mathrm{ClNPPd}$ : C, 64.72; H, 8.07; N, 2.04. Found: C, 64.85; H, 8.04; N, 1.91 .

Catalysis. To a $10 \mathrm{~mL}$ round-bottom flask equipped with condenser were placed palladium complex $\left(5 \times 10^{-3} \mathrm{mmol}\right)$, aryl halide ( $2 \mathrm{mmol}), \mathrm{K}_{2} \mathrm{CO}_{3}(3 \mathrm{mmol})$, phenylboronic acid (3 $\mathrm{mmol})$, and solvent $(5 \mathrm{~mL})$. The mixture was heated under reflux for a certain period of time. Upon cooling, the reaction mixture was poured into diluted hydrochloric acid (10\%) and extracted with dichloromethane. The extract was dried, concentrated, and analyzed by ${ }^{1} \mathrm{H}$ NMR spectroscopy. Results of the coupling reactions are listed in Table 3.

Decomposition of Palladacycles in the Presence of Aryl Halides or Arylboronic Acids. To a $10 \mathrm{~mL}$ roundbottom flask equipped with condenser was placed palladium complex $\left(1.0 \times 10^{-2} \mathrm{mmol}\right), \mathrm{K}_{2} \mathrm{CO}_{3}(2.0 \mathrm{mmol})$, and aryl halides or arylboronic acid in ethanol $(2 \mathrm{~mL})$. The resulting mixture was stirred with heating. An aliquot from the reaction mixture was analyzed by ${ }^{1} \mathrm{H}$ NMR. The results are summarized in Table 4.

Crystallography. Crystals suitable for X-ray determination were obtained for $\mathbf{3 a}, \mathbf{5 b}, \mathbf{d}$, and $\mathbf{7}$ by slow diffusion of hexane into a dichloromethane solution at room temperature. Cell parameters were determined by a Siemens SMART CCD diffractometer. Crystal data of these complexes are listed in Table 5. Other crystallographic data are deposited as Supporting Information.

Acknowledgment. We thank the National Science Council for financial support (NSC92-2113-M-002-037).

Supporting Information Available: Complete description of the X-ray crystallographic structure determination of $\mathbf{3 a}, \mathbf{5 b}, \mathbf{d}$, and $\mathbf{7}$ including tables of crystal data, atomic coordinates, isotropic and anisotropic thermal parameters, and bond distances and angles. This material is available free of charge via the Internet at http://pubs.acs.org.

OM049125T 